\title{
STAIN MANDAILING NATAL PUBLIC COMMUNICATION IN THE APPLICATION OF FACE-TO-FACE LEARNING DURING THE COVID-19 PANDEMIC
}

\author{
Ahmad Salman Farid \\ Sekolah Tinggi Agama Islam Negeri Mandailing Natal \\ ahmadsalmanfarid@stain-madina.ac.id
}

\begin{abstract}
The application of face-to-face learning during the Covid-19 pandemic needs to be conveyed appropriately to the public so that it requires public communication. The applicable face-to-face meeting policy needs to be reviewed so that there are no errors in the delivery of messages and feedback received by STAIN Mandailing Natal. This study aims to find out how the public communication of STAIN Mandailing Natal in the application of face-to-face learning during the Covid-19 pandemic with a qualitative descriptive method. The description of the research results shows that the public communication conducted by STAIN Mandailing Natal from the aspect of openness, the challenge is that it is difficult to convince students to maintain health protocols. STAIN Mandailing Natal has used Facebook, Whatsapp and the website as an option to communicate with students. The stakeholders collaborate in communication with various parties including the head of the study program, coordination across student associations of the study program and is carried out directly.
\end{abstract}

Keywords: Public Communication, Face-to-face Learning, Covid-19 Pandemic

\begin{abstract}
Abstrak
Penerapan Pembelajaran Tatap Muka di masa pandemi Covid-19 perlu disampaikan secara tepat kepada publik sehingga memerlukan komunikasi publik. Kebijakan pertemuan tatap muka yang berlaku perlu ditinjau agar tidak ada kesalahan dalam penyampaian pesan dan umpan balik yang diterima oleh STAIN Mandailing Natal. Penelitian ini bertujuan untuk mengetahui bagaimana komunikasi publik STAIN Mandailing Natal dalam penerapan pembelajaran tatap muka di masa pandemi Covid-19 dengan metode deskriptif kualitatif. Uraian hasil penelitian menunjukkan bahwa komunikasi publik yang dilakukan oleh STAIN Mandailing Natal dari aspek keterbukaan tantangannya adalah sulit meyakinkan mahasiswa untuk menjaga protokol kesehatan. STAIN Mandailing Natal telah menggunakan Facebook, Whatsapp dan website sebagai pilihan berkomunikasi dengan mahasiswa. Para pemangku kepentingan melakukan kerjasama komunikasi dengan berbagai pihak termasuk ketua program studi, koordinasi lintas himpunan mahasiswa program studi serta dilakukan secara langsung. Kata kunci : Komunikasi Publik, Pembelajaran Tatap Muka, Pandemi Covid-19
\end{abstract}


Komunike, Volume XIII, No. 2 Desember 2021

\section{A. INTRODUCTION}

During the Internet of Things era, students still lacked understanding of communication, social media could be one of the triggers for noise in an effort to control the Covid-19 public disaster. At this time, any news or discourse about Covid-19 will always be in the public spotlight. Then, how should the perfect state of communication be patterned.

McLuhan gave birth to the concept of a global village which in this concept states that the world is like a small village with no partitions between various countries. Long distance is not a barrier to communicate with each other. When a message is communicated via the internet, so that anyone can see and know it. Students have a symbiotic relationship with technology that uses media. This is the concept of media theory. ${ }^{1}$

Thus, public communication during the Covid-19 pandemic requires transparency and public confidence. Also, it is necessary to have an official counter against data and 'wild' issues that hit and crowd students through social media so that the public's

${ }^{1}$ McLuhan, M., \& Powers, B. R. 1989. The global village: Transformations in world life and media in the 21 st century. Communication and society. confidence can be obtained by the authorities. Therefore, the main purpose of public communication is a change of attitude due to the message being informed, so that messages about the dangers of Covid-19 can be trusted. The emergence of student confidence as one of the markers of compliance with implementing health protocols is a symptom of the success of public communication itself.

Submission of messages in public communication is very vulnerable to noise (constraints). This is because public communication tends to be oneway communication. For Rakhmat there are 5 types of obstacles in public communication $^{2}$, among others, initial, mechanical obstacles, namely obstacles caused by the presence of sound or other noise near the sender of the message; Second, personal problems, namely the physical condition of the communicator (message sender) and/or communicant (message recipient) who are tired, hungry, or sleepy, including psychological conditions such as lack of attention, boredom, and other psychological pressures. ; third, semantic constraints, is the obstacle

${ }^{2}$ Rakhmat, Jalaludin. 2007. Psikologi komunikasi, bandung: Remaja Rosdakarya 
caused by the comparison of meanings that are understood by the communicator as the source of data and the communicant as the recipient of the data. This matter generally occurs because of the choice of diction, terms, symbols, or jargon with multiple interpretations that can be twisted so that it becomes complicated among students; fourth, the constraint of the existence of cultural comparisons, is that cultural comparisons between communicators and communicants can make the message informed out of balance and become less efficient; and fifth, the problem of the absence of feedback, is that there is no feedback from the communicant to the communicator and this can make the communicant feel bored with the conditions of communication in public spaces.

The pros and cons of how students understand Covid-19 are reflected in the hegemony of communication on social media. This is due to the lack of comprehensive information due to disruption of public communication. Moreover, the length of the Covid-19 pandemic has also exacerbated disturbances in public communication. As a real example, personal disorders and semantic disorders that afflict communicators and communicants such as fatigue, psychological conditions and the use of diction can cause tension and emotions which if not properly patterned can lead to courtrooms. And, this is actually very undesirable by both communicators and communicants in the context of public communication.

Currently, this is already happening among students and so that it can be reduced, the theory of reasoned action and theory of planned behavior which was initiated by Icek Ajzen ${ }^{3}$ worth pondering. This theory basically formulates a combination of personal attitudes, perceived norms of others, and motivation to comply with any predictor of behavior. This theory is based on expectancy values which postulates that attitudes are evoked by beliefs about behaviors that can lead to certain effects. In this context, attitudes, beliefs, behavior and logical-sense consequences to the dangers of Covid-19 need to be synergized together between STAIN Mandailing Natal as communicators and students as communicants. The intended synergy can be pursued by changing the pattern of

\footnotetext{
${ }^{3}$ Ajzen, Icek. 2005. Attitudes, Personalitiy, and Behavior, Edisi Kedua. New. York: Open University Press
} 
verbal and non-verbal communication at each level. For example, government officials do not create crowds even for photo purposes or ceremonial events. The PR team and the head of the study program in social media did not set an example that was against health protocols and preferred the correct diction and was easily understood by students. This is important to do to reduce miscommunication and noise among students.

Student obedience and discipline in implementing health protocols will be higher when STAIN Mandailing Natal is consistent in text and motion behavior such as face-to-face lectures. This is because visual actions in the midst of the fact that students with low literacy and lack of communication understanding will tend to imitate. Patron-client students really need a mirror or good example in implementing health protocols in their daily activities.

Students and the academic community also need to obey the rules and not take advantage of the weakness of a rule such as the classic problem that occurs, namely weak supervision, endorsement and the existence of multiple interpretations of existing rules. For this reason, serious steps, including improving communication patterns and being aware of disruptions in public communication, are important for both STAIN Mandailing Natal and students to understand and agree on for the sake of intensive-massive control of Covid-19.

\section{B. LITERATURE REVIEW}

Public communication is defined as the activity of understanding, designing, implementing, and successful communication campaigns within a framework to serve the public interest. Programs in public communications use communication to inform or persuade, build relationships, and to encourage open dialogue within organizations or communities towards long-term solutions. This is done by crafting a successful message through the application of research, theory, technical knowledge, and sound design principles.

According to Dennis Dijkzeul and Markus Moke, public communication is defined as communication activities and strategies aimed at the target audience. The purpose of public communication is to provide information to the target audience and to increase awareness and 
influence the attitudes or behavior of the target audience. ${ }^{4}$

Meanwhile, Judy Pearson and Paul Nelson define public communication or public speaking as the process of using messages to create meaning in a situation where a source transmits a message to a recipient who provides feedback in the form of messages or nonverbal communication and sometimes in the form of questions and answers. In public communication, the source of the adjustment of the message sent to the recipient of the message in order to achieve maximum understanding. sometimes, virtually the recipient of the message can understand the message conveyed by the source of the message or even do not understand it at all. $^{5}$

\section{PUBLIC COMMUNICATION PARADIGM}

The way of communication between STAIN Mandailing Natal and students has changed very quickly. We can no longer be satisfied with just distributing press releases or simply making press conferences, there must be dialogue and

${ }^{4}$ Dijkzeul, Dennis \& Moke, Markus. 2005. Public Communication Strategies of International Humanitarian Organizations. Vol. 87, No. 860 ${ }^{5}$ Pearson, Judy C.. Paul E. Nelson, Scott Titsworth, Lynn Harter, 2003. Human Communication, New york: The McGraw-Hill Companies collaboration with students, for that STAIN Mandailing Natal public relations must be able to adapt to changing times. The choice of STAIN Mandailing Natal communication strategy is one of the keywords in measuring the effectiveness of delivering STAIN Mandailing Natal ideas, programs, and ideas to students in order to achieve higher education goals. The appropriate STAIN Mandailing Natal communication strategy, based on the packaging of quality supporting materials and data through a variety of contemporary communication channels, has become a strategic issue that needs to be used as the basis for improving the communication governance of STAIN Mandailing Natal.

The new communication paradigm of STAIN Mandailing Natal that puts forward creative innovations that are responsive to the present, which is adaptive to the development of the digital era, is an answer to the demands of transparency and accountability as well as building public trust (Public Trust) related to the Tri Dharma of Higher Education at STAIN Mandailing Natal. The implementation of the new paradigm in STAIN Mandailing Natal communication is a determining factor that determines the success of STAIN 
Komunike, Volume XIII, No. 2 Desember 2021

Mandailing Natal's work in the eyes of students and students. digital. Communication patterns in the digital era have caused the flow of information to flow rapidly and quickly.

\section{THE URGENCE OF GOVERNMENT COMMUNICATION TRANSFORMATION}

The shift in communication patterns in the digital era has made citizen journalism a new form of state, communication is now no longer a twostep communication model, but a multistep communication model, which positions individuals as a new force that can influence public opinion so that the presentation of data-rich material be the main (content is the king).

Observing the development of government communication patterns in the digital era has brought the consequence that the public relations officer of STAIN Mandailing Natal is actually no longer single, but all employees in the STAIN Mandailing Natal organization must be able to play a role as public relations for their work organization. This is in line with the change in the communication paradigm of STAIN Mandailing Natal where the delivery of a single and scheduled government communication in a traditional communication style,
Changes in communication patterns in the digital era, with increasingly massive internet penetration, are projected to accelerate the transformation to new communication patterns, which require changes in government communication patterns to the public. This situation is not without a fundamental reason, referring to the Global Digital Report ${ }^{6}$ Regarding internet users in Indonesia, it shows that it has reached 170 million people or around $61.8 \%$ of the population with a duration of internet use of 8 hours 51 minutes every day. From the statistical data above, Indonesia has actually entered the interactive communication era phase as a further stage of the development of the telecommunications era. This era is marked by the use of the internet as a new media (new media). This transformation confirms that the second media age, with a symmetrical and interactive pattern, has begun to shift the dominance of broadcast media such as newspapers, radio and television, news that is viral and becomes a trending topic in social media and often becomes the main news in mainstream media. The presence of the

\footnotetext{
6 https://datareportal.com/reports/digital-2021indonesia
} 
digital era and the shift in communication patterns,

STRATEGIC STEPS FOR STAIN MANDAILING NATAL COMMUNICATION TRANSFORMATION

The transformation of STAIN Mandailing Natal communication as a strategic step can be done by rearranging the strategic communication plan, as a roadmap for change with the current pattern, conducting market intelligence so that the public communication strategy is adapted to the recipient of the message. The existence of public relations practitioners, $P R$ or public information managers at the STAIN Mandailing Natal organization needs to get support from all existing human resources within the STAIN Mandailing Natal organization in order to optimize the synergy in accelerating the dissemination of information and the work achievements of government organizations.

The success of information dissemination and work achievements of government organizations needs to be supported by the preparation of quality content (content is the King) and accurate data as a single narrative as well as agenda setting material related to program performance and activities in order to gain public support and trust. This is very necessary in supporting the work agendas of the government as a whole, the strategic positioning of $H R$ as a public relations practitioner, $P R$ or public information manager.

In the United States (US), found that 44 percent of news media in the US are influenced by public relations practitioners, who make the output of public relations practitioners' work as agenda setting. In fact, prestigious newspapers such as the Washington Post and New York Times derive more than half of their content from press releases and conferences. $^{7}$ Therefore, public relations practitioners must be able to transform the mindset from working linearly and business as usual to being visionary (think ahead) and creative and innovative, think holistically and across sectors (think across), have competencies like a chief editor or newsroom head, especially in improving the ability to produce public communication content that is interesting, denser, contained, innovative and creative by prioritizing the use of social media in accelerating its dissemination.

${ }^{7}$ Grunig, James E, Hunt, Todd T. 1984. Managing Public Relations. United States of America: Harcourt Brace Javanovich College Publisher. 
Komunike, Volume XIII, No. 2 Desember 2021

The STAIN Mandailing Natal communication strategy developed must be able to serve the needs of public information (service delivery culture), form a positive image of the institution, provide updates on what has been, is, and will be done, what are the benefits for students, and embraces feedback from the public. Public communication practitioners must be able to act as eyes and ears.

Corporate level strategy in designing strategic management of STAIN Mandailing Natal communication must be able to be translated concretely up to the functional level strategy level, through planning, implementation and evaluation as an integrated framework, this is needed in providing direction for the organization's strategic plan so that it is able to adapt to changes. Rapidly changing external strategic environment. Changes in work culture (corporate culture) from output-oriented to outcome-and benefit-oriented need to be continuously developed within the organization so that existing public relations practitioners do not only struggle to spend all their energy and time on old patterns of work, such as preparing releases, preparing press conferences, reporting. and documentation.
For this reason, communication practitioners of STAIN Mandailing Natal must be required to continue to develop competencies and change the mindset of working from mere technical services to being a public communication practitioner who is visionary (think ahead) and works in an innovative and creative rhythm, thinks holistically and across sectors (think across) so that it happens. transformation towards the performance of Tri Dharma STAIN Mandailing Natal which is able to adapt to the development of the strategic environment.

In developing the competence of public relations $(P R)$ officers or practitioners, especially increasing their skills regarding online media, it is possible to continue to cultivate new habits that are conducive to supporting changes in the government communication paradigm, among others, simply starting with institutionalizing blogging culture, creating personal blogs for public relations. practice writing skills in online media. Netizens, by becoming active internet users, will share and publish actual info, be active in online forums or students in cyberspace. The PR team can actively develop strategies by Googling, for 
example with the keyword "social media strategy".

STAIN Mandailing Natal communication HR development as a prerequisite in supporting the realization of think ahead, think strategically like editor-in-chief in planning and making news framing related to what has been, is being and will be done by STAIN Mandailing Natal. Determination of various channeling to be used and target audience to be targeted based on media monitoring referring to certain keywords through goggle alerts. New patterns by optimizing student involvement need to be continuously developed by exploring feedback, student involvement must be the focus of attention interactively in absorbing student aspirations, especially to find out the outcomes of programs and activities.

Determination of various channeling to be used and target audience to be targeted based on media monitoring referring to certain keywords through goggle alerts. New patterns by optimizing student involvement need to be continuously developed by exploring feedback, student involvement must be the focus of attention interactively in absorbing student aspirations, especially to find out the outcomes of programs and activities. Determination of various channeling to be used and target audience to be targeted based on media monitoring referring to certain keywords through goggle alerts. New patterns by optimizing student involvement need to be continuously developed by exploring feedback, student involvement must be the focus of attention interactively in absorbing student aspirations, especially to find out the outcomes of programs and activities.

The ways of presenting and packaging public communications must refer to the current packaging that is trending and easy to digest, without reducing the substantial meaning of the message, presentation models through infographics, blogs, animations and news analysis modeling with real-time coding technology. In the digital media era, STAIN Mandailing Natal communication is not enough to convey information, but must be managed in an integrated manner by building synergy and coordination between data and information on policies and programs across sectors.

Therefore, The integrated communication dashboard of STAIN Mandailing Natal needs to continue to be developed through the data interface as one big data that can be a shared reference as material for dissemination 
Komunike, Volume XIII, No. 2 Desember 2021

of STAIN Mandailing Natal integrated and well-coordinated
communication as well as a leadership management.
control tool in making changes behind the stage (manufacturing quality) and in front of the stage (service quality).

In communicating, public relations practitioners of STAIN Mandailing Natal need to continue to streamline and streamline their communications, by increasing synergy and removing sectoral barriers, so that STAIN Mandailing Natal's public communications can support conversations in digital media to win "air battles while creating a conducive atmosphere regarding positive image of STAIN Mandailing Natal. Change in mindset from owning economy to sharing economy in the context of public communication materials that need to be continued, the concept of sharing content, to get a single narrative into a necessity, the loss of shackles with conventional and sectoral mindsets and then use new patterns with innovation and creativity so that effectiveness and efficiency of public communication can be achieved. Like a choir and symphony orchestra, the harmonization of communication management at STAIN Mandailing Natal is very important, considering that there are many topics, agendas and activities that require

\section{RESEARCH METHOD}

This research has been done using a qualitative descriptive method and the object of this research is STAIN Mandailing Natal. The focus of this study is on the public communication of STAIN Mandailing Natal in communicating face-to-face learning activities during the COVID-19 period. Based on the theory put forward by Agusly Irawan with several aspects, namely: Openness ${ }^{8}$

Direct communication with the public; Using all communication channels that are considered relevant, not only limited to the national mass media, but also conducting coordinated cross-study communication on an issue, not creating conflict or duplication of messages. The data collection methods used were interviews with head of STAIN Mandailing Natal and vice chairman of academic and institutional of STAIN Mandailing Natal, field observations, and literature studies related to the research topic. Data analysis includes

\footnotetext{
${ }^{8}$ Aritonang, Agusly Irawan. 2011. Kebijakan Komunikasi di Indonesia: Gambaran Implementasi UU No. 14 Tahun 2008 tentang Keterbukaan Informasi Publik dalam Jurnal Komunikasi ASPIKOM Volume 1, No 3, Juli 2011. Hal.261-278.
} 
data reduction, namely classifying data which is then presented in the narratives which are then used to draw conclusions.

\section{RESULTS AND DISCUSSION OPENNESS}

The open STAIN Mandailing Natal is a concept that discusses openness and interactive information that STAIN Mandailing Natal has built for the world of education to students. In the context of communication to the public, an open Mandailing Natal STAIN means the disclosure of information and data that the public has the right to own. STAIN Mandailing Natal, which is open, is not only carried out during normal government situations but also in crisis situations. In the context of the Corona virus, the open STAIN Mandailing Natal became a means for students to accept openness in sharing data with the public and build models to estimate the spread of the virus. ${ }^{9}$

Then, One of the open and most important elements in dealing with the corona virus pandemic is the transparency of data and information sourced from communications with the

${ }^{9}$ Farizi, S. Al, \& Harmawan, B. N. 2020. Data Transparency and Information Sharing: Coronavirus Prevention Problems in Indonesia. Jurnal Administrasi Kesehatan Indonesia, 8 (2), 35.https://doi.org/10.20473/jaki.v8i2.2020.35-50 public conducted by STAIN Mandailing Natal. At the beginning of the emergence of the Corona virus outbreak in Mandailing Natal Regency in March, not long after its appearance in Indonesia, STAIN Mandailing Natal received a lot of attention related to face-to-face learning in the COVID-19 situation.

The delay in making the Corona virus information channel so that there is no information about the spread of the disease and how to track the virus, even the contradictory attitude of STAIN Mandailing Natal in providing information to the public through various policy messages. As a result of the weak information received by students, prompting deeper panic among students and even causing noise and failing to focus on students is reflected in the emergence of a desire for online learning.

This situation is about to talk about student distrust regarding the disclosure of information conveyed by STAIN Mandailing Natal in dealing with COVID-19. This situation continues to worsen, because every day students are bombarded with issues related to the dangers of COVID-19, ranging from drugs that are not able to ward off this virus, as well as concepts that are not certain about the truth related to this 
Komunike, Volume XIII, No. 2 Desember 2021

pandemic. STAIN Mandailing Natal's unresponsiveness that appeared at the beginning of handling related to information reflected in the lack of openness was the impact of a problem that had long been acute in STAIN Mandailing Natal, namely the building of a public communication system that was still weak. In addition, the case tracking system, which is also only subjective, weakens the tracking system for infected cases in the Mandailing Natal District. So that creates limited information that is conveyed to the public.

The number of new communication media, which also brings an unstoppable flow of information, makes information related to the handling of COVID-19 take various forms in students' heads, meanwhile STAIN Mandailing Natal has not been able to provide a striking color as the holder of a valid information reference authority. The biggest challenge of STAIN Mandailing Natal in public communication to implement face-to-face learning during the COVID19 period is the difficulty of convincing students. This is due to student distrust arising from too many information channels reporting related to the handling and description of COVID-19. Meanwhile, STAIN Mandailing Natal is still limited in terms of human resources and facilities and infrastructure.

\section{DIRECT PUBLIC COMMUNICATION}

Communication is the process of transferring understanding in the form of ideas or information from one person to another. ${ }^{10}$ Submission of information carried out, through any media, has one principle that must be adhered to, namely the information conveyed must reach the target if it does not arrive or experiences bias, this is where the problem begins. Communication does not only provide meaning but must be understood by the parties invited to communicate because communication is a factor in the success of an organization.

Circulars, appeals and other similar forms of communication are a medium or pattern of communicating something in the context of public communication. Submission of public information is of course carried out in public spaces as a medium where public communication is carried out. Prior to the COVID-19 pandemic, public spaces were present in the fields, in halls, and in other places used by the government in an effort to communicate its policies directly to the

\footnotetext{
${ }^{10}$ Tarigan, H. G. 2015. Berbicara Sebagai Suatu Keterampilan Berbahasa. Bandung: Angkasa
} 
public through counseling, socialization and education.

COVID-19 can be said to have knocked down public spaces that serve as a medium of public communication directly to the public. This is because public spaces contain a lot of uncontrolled mass mobility, which has the potential to create new clusters of the spread of COVID-19. So that, the government's direct reach to the public in delivering public information is limited to electronic media that are able to present a stage for the government to deliver information to the public.

The consequence that must be accepted with the use of this media is that there is too much noise in the use of social media. In addition to using social media, STAIN Mandailing Natal also conducts public communication using discussion forums through webinars aimed at campaigning and educating students regarding health protocols in face-to-face learning during COVID-19.

\section{USING NEW MEDIA}

Media comes from the Latin word medium, which literally means intermediary, conveyer, or distributor. ${ }^{11}$ Some of the limitations of media

\footnotetext{
${ }^{11}$ Arief S Sadiman, dkk. 2007. Media Pendidikan. Jakarta: PT. Raja Grafindo Persada
}

according to experts 1 . Media means the message-carrying technology needed for instructional purposes 2. Media means a means of communication in printed or audible form, including hardware technology 3. Media means a physical means to deliver teaching materials In achieving the objectives and goals of an organization or individual, need to improve its efficiency or effectiveness. ${ }^{12}$ This increase is largely dependent on facilities and infrastructure. In other words, the interaction communication relationship will run smoothly and achieve maximum results, if used tools called communication media.

In face-to-face learning, STAIN Mandailing Natal has the intent and purpose of providing understanding to students related to COVID-19, campaigning for health protocols, and giving other appeals that have one main goal, namely breaking the chain of the spread of COVID-19. Therefore, it is necessary to increase efficiency and effectiveness so that this goal can be achieved. The achievement of this goal will greatly depend on the interaction communication relationship between students as communicants and the STAIN Mandailing Natal campus as

\footnotetext{
${ }^{12}$ Syaibani, Yunus Ahmad, dkk. 2011. New Media Teori dan Aplikasi. Karanganyar: Lindu Pustaka
} 
Komunike, Volume XIII, No. 2 Desember 2021

communicators, so a tool called or newspapers and radio, but is able to communication media really needs to be used by STAIN Mandailing Natal to ensure communication interactions between the two parties run smoothly. Submission of information through any media has one principle that must be adhered to.

One of the paths that must be taken by public information to reach the target is through the media. The media that will deliver this information to its destination can influence the bias or failure to arrive at the intent of the information conveyed. Based on the results of interviews with head of STAIN Mandailing Natal and Vice Chairman, students obtained more information related to COVID-19 through social media Facebook.

In addition, in an effort to educate students, campaigns must be carried out through leaflets, pamphlets, posters and also websites that display data on the number of patients being treated as well as presentations of infected cases in Mandailing Natal Regency. The use of new communication media such as social media in communication efforts related to face-to-face learning during COVID-19, shows that STAIN Mandailing Natal does not limit the delivery of information only through national mass media such as television adapt slowly to the times. In addition, STAIN Mandailing Natal also conducts public communication through web seminars, partnerships with community organizations, discussion forums, Website, Whatsapp and other communication media.

\section{E. CONCLUSION}

After parsing and analyzing the information obtained and based on the results of research and discussion, it can be concluded that:

a. Transparency, in terms of openness STAIN Mandailing Natal has tried various things to ensure the disclosure of information to the public, however, the toughest challenge is trying to convince the public that the information conveyed is a truth that is not covered up. Public information disclosure is a legal guarantee for everyone to obtain information as one of the public rights of every citizen.

b. Direct communication with the public is carried out without creating a mass crowd through direct messages from social media, as well as utilizing all new communication media and collaboration with the head of the study program to educate students. 
c. Using communication channels that are considered relevant is not only limited to national mass media, namely the use of social media or new communication media, leaflets, pamphlets, posters, web seminars, Facebook, Whatsapp and other media.

d. Conduct coordinated cross-study communication on an issue, not creating conflict issues or avoiding duplication of messages that tend to make noise, but also direct meetings through chat media in WhatsApp groups.

\section{Suggestion}

1. The need for improvement in the public communication system of STAIN Mandailing Natal.

2. Must develop the websites of STAIN Mandailing Natal and study programs to be more interactive in delivering information to the public.

3. In the use of social media, STAIN Mandailing Natal is a reference for student information that has the power to have a significant influence.

STAIN Mandailing Natal needs to further strengthen coordination across study programs in conveying information about an issue to the public so that there is no more duplication of messages or information bias.

\section{F. REFERENCE}

Ajzen, Icek. 2005. Attitudes, Personalitiy, and Behavior, Edisi Kedua. New. York: Open University Press

Arief S Sadiman, dkk. 2007. Media Pendidikan. Jakarta: PT. Raja Grafindo Persada

Aritonang, Agusly Irawan. 2011. Kebijakan Komunikasi di Indonesia: Gambaran Implementasi UU No. 14 Tahun 2008 tentang Keterbukaan Informasi Publik dalam Jurnal Komunikasi ASPIKOM Volume 1, No 3, Juli 2011. Hal.261-278.

Dijkzeul, Dennis \& Moke, Markus. 2005. Public Communication Strategies of International Humanitarian Organizations. Vol. 87, No. 860

Farizi, S. Al, \& Harmawan, B. N. 2020. Data Transparency and Information Sharing: Coronavirus Prevention Problems in Indonesia. Jurnal Administrasi Kesehatan Indonesia, $8(2)$,

35.https://doi.org/10.20473/jaki.v8i2. 2020.35-50

Grunig, James E, Hunt, Todd T. 1984. Managing Public Relations. United States of America: Harcourt Brace Javanovich College Publisher.

https://datareportal.com/reports/digital2021-indonesia diakses pada 08 Oktober 2021

McLuhan, M., \& Powers, B. R. 1989. The global village: Transformations 
in world life and media in the $21 \mathrm{st}$ century. Communication and society.

Pearson, Judy C.. Paul E. Nelson, Scott Titsworth, Lynn Harter, 2003. Human Communication, New york: The McGraw-Hill Companies

Rakhmat, Jalaludin. 2007. Psikologi komunikasi, Bandung: Remaja Rosdakarya
Syaibani, Yunus Ahmad, dkk. 2011. New Media Teori dan Aplikasi. Karanganyar: Lindu Pustaka

Tarigan, H. G. 2015. Berbicara Sebagai Suatu Keterampilan Berbahasa. Bandung: Angkasa 